\title{
Paleomagnetic study of Utror Volcanic Formation: Remagnetizations and postfolding rotations in Utror area, Kohistan arc, northern Pakistan
}

\author{
Mirza Naseer Ahmad ${ }^{1}$, Mitsuo Yoshida ${ }^{2}$, and Yoshiki Fujiwara ${ }^{1}$ \\ ${ }^{1}$ Division of Earth and Planetary Sciences, Graduate School of Science, Hokkaido University, Sapporo, Japan \\ ${ }^{2}$ Geoscience Analysis Centre, Tokyo, Japan
}

(Received March 13, 1999; Revised April 22, 2000; Accepted April 28, 2000)

\begin{abstract}
The Utror Volcanic Formation forms a NE-SW belt with in Kohistan island arc, which lies between the Indian and Eurasian continents in the western Himalayas of northern Pakistan. The Utror Volcanic Formation formed during Late Paleocene, when Kohistan existed as an Andean-type arc on the southern margin of Eurasia. Five to ten block samples were collected from 17 sites of the formation for paleomagnetic studies. Magnetic minerals that serve as remanent carriers are maghemite, magnetite, hematite and titanohematite. Magnetite, hematite, and titanohematite carry the characteristic remanent magnetization (ChRM). The declination values of ChRM are highly discordant before and after structural correction. While inclination values show uniformity in geographic coordinates. The ChRM carried by magnetite yields downward inclinations, whereas the ChRM carried by hematite or titanohematite have upward inclinations in geographic coordinates. The correlation between polarity state and magnetic mineralogy suggests that the acquisition of magnetization occurred during two distinct time intervals. An inclination only fold test of ChRM of these two mineral assemblages indicates that they are post-folding magnetizations. The calculated paleolatitudes for ChRM carried by magnetite and hematite or titanohematite are $9 \pm 4^{\circ} \mathrm{N}$ and $13 \pm 4^{\circ} \mathrm{N}$ respectively. A comparison of these paleolatitudes with the Indian apparent polar wander path (APWP) shows that the remagnetization likely happened between 55 to $45 \mathrm{Ma}$. Discordant declinations indicate that these volcanics suffered local rotations after remagnetization event.
\end{abstract}

\section{Introduction}

The Himalaya, almost $3000 \mathrm{~km}$ long, contains the highest peaks on our globe and was formed by collision of the Indian and Eurasian continents (Le Fort, 1996; Searle, 1996). The northwestern part of Himalayan collision belt consists of island arc sequence, termed as Kohistan island arc, captured between the two colliding continents (Tahirkheli et al., 1979). In this paper new paleomagnetic results are presented from Utror Volcanic Formation of western Kohistan.

\section{Geology and Sampling}

The Kohistan terrane of western Trans Himalaya contains a remarkable cross section through an island arc sequence which developed as result of northward subduction of neoTethyan oceanic crust beneath Eurasia during Late Jurassic and Early Cretaceous (Tahirkheli et al., 1979). From the mafic bulk composition of the Kohistan, presence of pillowed lavas and marine sediments it has been inferred that Kohistan originated as an intra-oceanic arc (Khan et al., 1997). The isotopic data demonstrate the involvement of enriched, DUPAL-type mantle, suggesting that the Kohistan arc formed at or south of present equator (Khan et al., 1997). The intra-oceanic phase of Kohistan lasted up to between $102 \mathrm{Ma}$ and $85 \mathrm{Ma}$, when the arc collided with Eurasia across northern suture (Treloar et al., 1996; Petterson and Windley, 1985).

Copy right (c) The Society of Geomagnetism and Earth, Planetary and Space Sciences (SGEPSS); The Seismological Society of Japan; The Volcanological Society of Japan; The Geodetic Society of Japan; The Japanese Society for Planetary Sciences.
After this time the arc remained as an Andean-type margin till it's collision with Indian continent in the Eocene (age of collision is from Coward et al., 1987). The arc can be divided broadly in to six components on the basis of structure and lithology (Searle, 1991). They are 1) Jijal Ultramafic Complex, 2) Kamila Amphibolite, 3) Chilas Complex, 4) Chalt Volcanic Group, 5) Yasin Group, and 6) Kohistan batholith (Fig. 1).

The northward movement of Indian continent continued even after the collision and led to the formation of western Himalayan Syntaxial belt as well as oroclinal bend of the Himalayan mountain belt (Klootwijk et al., 1985). One of the major syntaxes of western Himalayan syntaxial belt is Nanga Parbat syntaxis (NPS) which separates the Kohistan and Ladakh terranes (Fig. 1). It is believed that these terranes were continuous before the formation of NPS (Searle, 1991).

Stratigraphically, the western part of the Kohistan arc, which is the studied area, is divided in two groups: Kalam and Dir (Sullivan et al., 1993) (Fig. 2). The Kalam Group is comprised of schists and metavolcanics. While the Dir Group is comprised of the Barul Banda Slate Formation and the Utror Volcanic Formation. The Utror Volcanic Formation consists of volcanic breccias, volcanic sandstone and siltstones, lava flows and pyroclastic flows. These volcanics are andesites, rhyolites, and dacites. These volcanics were accumulated in subaerial environment and represent typical continental marginal arc series volcanics (Sullivan et al., 1993). Latter this idea was contradicted on the basis of detail mapping and 


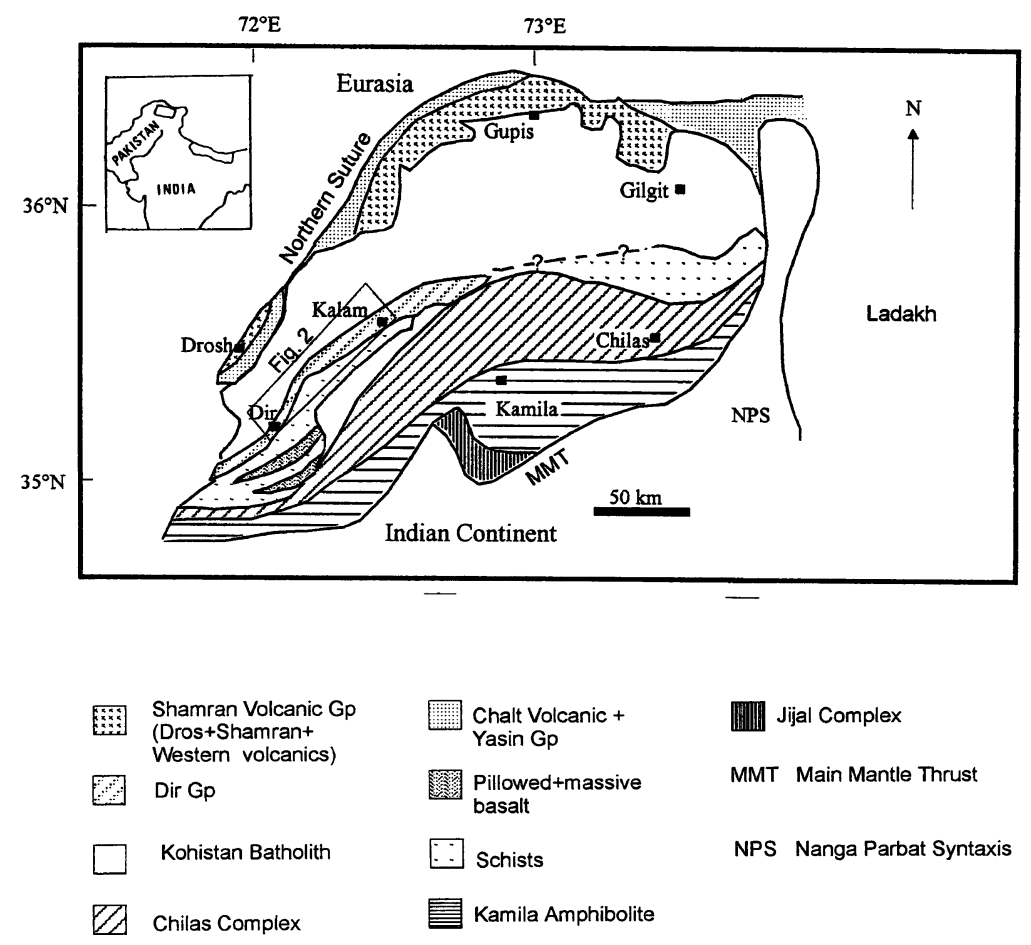

Fig. 1. Simplified Geological map of Kohistan arc (modified after Treloar et al., 1996).

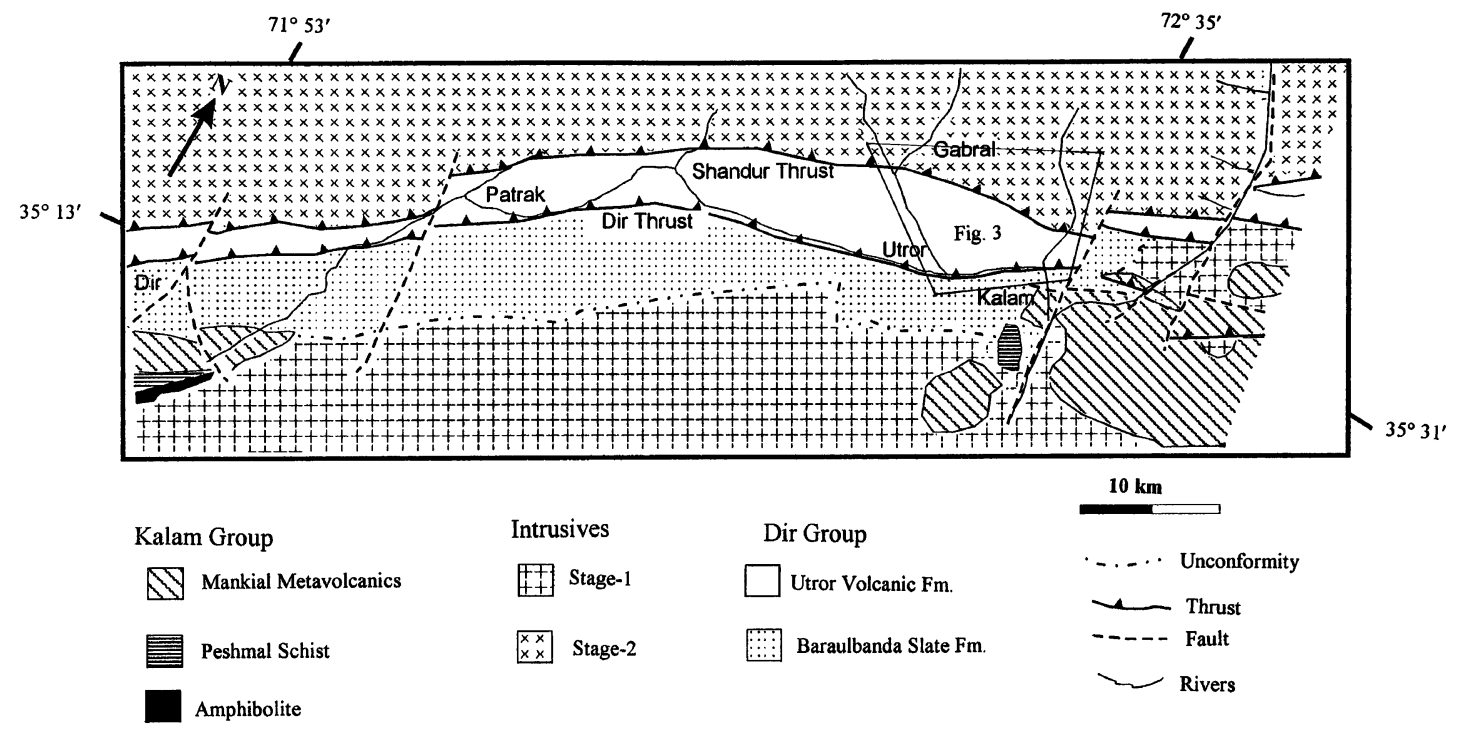

Fig. 2. Geological map of study area (modified after Sullivan et al., 1993).

detail geochemical data. These volcanics resembles mafic lava proportions in mature oceanic arcs (Shah and Shervais, 1999). The abundance of mafic lava proportions at the time of Andean margin phase of the arc is explained by underlying crust, which consists of accreted intra-oceanic arc volcanic and plutonic rocks, and mafic relative to normal continental margins (Shah and Shervais, 1999). A basaltic andesitic lava in the Kalam area (i.e. of Utror Volcanic Formation) has ${ }^{40} \mathrm{Ar}$ ${ }^{39}$ Ar hornblende age about $55 \pm 2 \mathrm{Ma}$ (Treloar et al., 1989, sample no. K210). This has been interpreted as extrusive age for the volcanics. In the north of the Utror Volcanic Forma- tion there is a pluton (stage-2) yielding $\mathrm{K}-\mathrm{Ar}$ and $\mathrm{Ar}-\mathrm{Ar}$ ages of 48-45 Ma for hornblends (Treloar et al., 1989, sample no. K199, PL122, and PL123; Sullivan et al., 1993) (Fig. 2). In the south the Utror Volcanics Formation has thrusted contact with Barul Banda Slate Formation. Interbedded limestones with in these slates have yielded a Thanetian (60.2-54.9) marine fauna of Miscellanea miscella and Actinosiphon tibeticus (Sullivan et al., 1993). Baraul Banda slate Formation has unconformable contact with older pluton (stage-1) having hornblende ages of 76-78 Ma age (Treloar et al., 1989, sample no. K193 and PL189; Sullivan et al., 1993). For the 


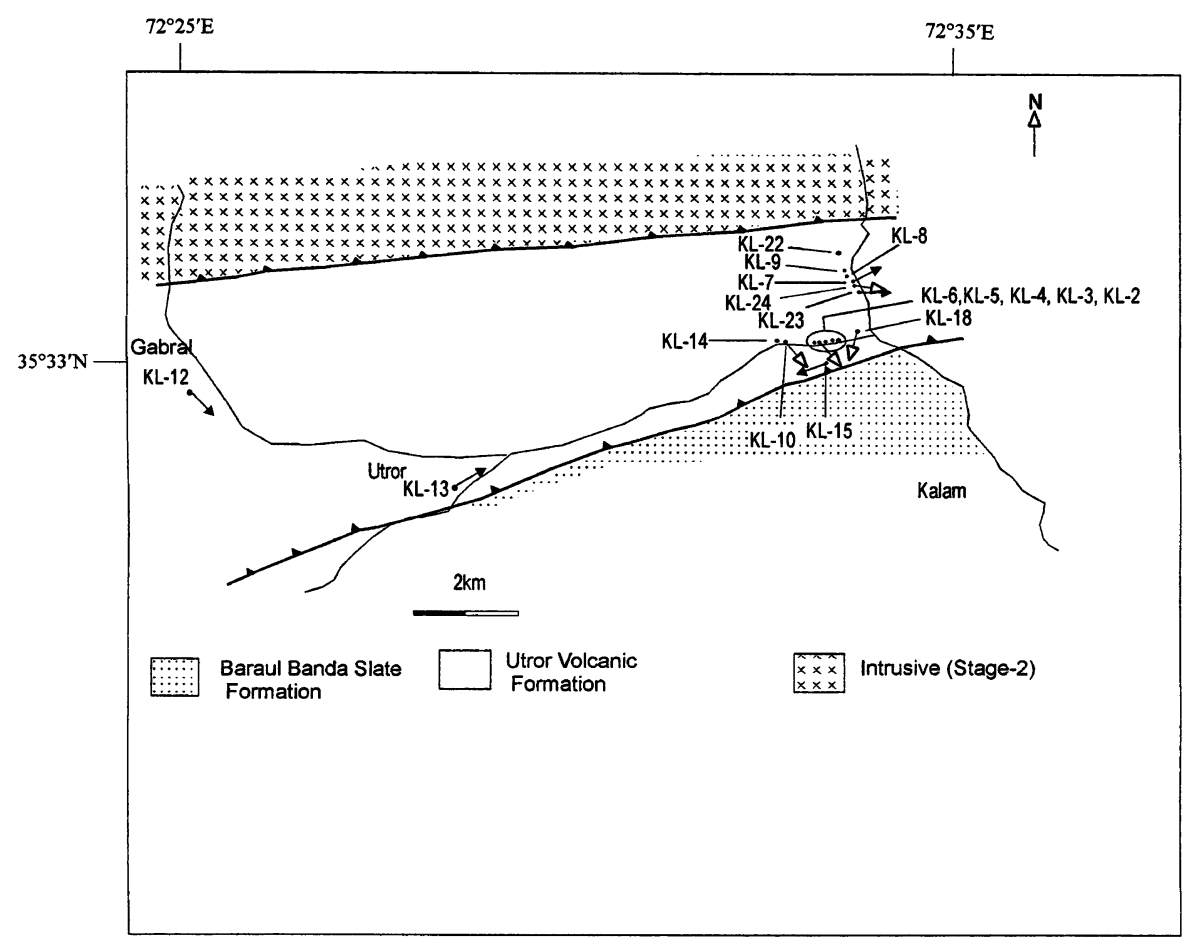

Fig. 3. Geological map of the studied area showing sampling localities. The angle of arrows from north at each locality indicate the declination value of ChRM observed at that locality. Solid arrows show that inclination values are downward while hollow arrows represent upward inclinations. For the sites enclosed by the circle only one declination vector is plotted for all other sites almost same declination value is observed. For the sites without any arrows ChRM could not be achieved.

present paleomagnetic study, 5 to 10 oriented block samples from 17 sites of Utror Volcanic Formation collected. Orientation of the samples was done by magnetic compass. Volcanic siltones are well bedded which can provide data for structural correction of paleomagnetic directions, whereas layering in the case of rhyolitic lava flows serves as good structural marker. In volcanic breccias, alignment of lithoclasts defines the bedding. Figure 3 shows the geological map of the investigation area and the location of sampling sites.

\section{Magnetic Mineralogy}

In order to investigate magnetic mineralogy, low field bulk magnetic susceptibility measurements as function of temperature up to $700^{\circ} \mathrm{C}$ and isothermal remanent magnetization acquisition experiment (IRM) up to $400 \mathrm{mT}$ followed by step wise thermal demagnetization in seven steps keeping $100^{\circ} \mathrm{C}$ interval up to $700^{\circ} \mathrm{C}$ was performed on representative samples of selected sites. Samples from most of the sites of Utror Volcanic Formation indicate sharp decrease in the susceptibility at about $550^{\circ} \mathrm{C}$ (Fig. 4) and a sample from site $\mathrm{KL}-13$ shows partial drop in susceptibility between $300^{\circ} \mathrm{C}$ to $400^{\circ} \mathrm{C}$. In all the cases bulk susceptibility decreases in cooling curve comparing with heating curve. This may be because of partial oxidation of magnetite to low susceptibility hematite during the experiment. The susceptibility drops at about $550^{\circ} \mathrm{C}$ and between $300^{\circ} \mathrm{C}$ and $400^{\circ} \mathrm{C}$ may due to the presence of magnetite/Ti-poor titanomagnetite and maghemite respectively.

IRM acquisition curves followed by thermal demagnetization of acquired IRM demonstrate four types of patterns
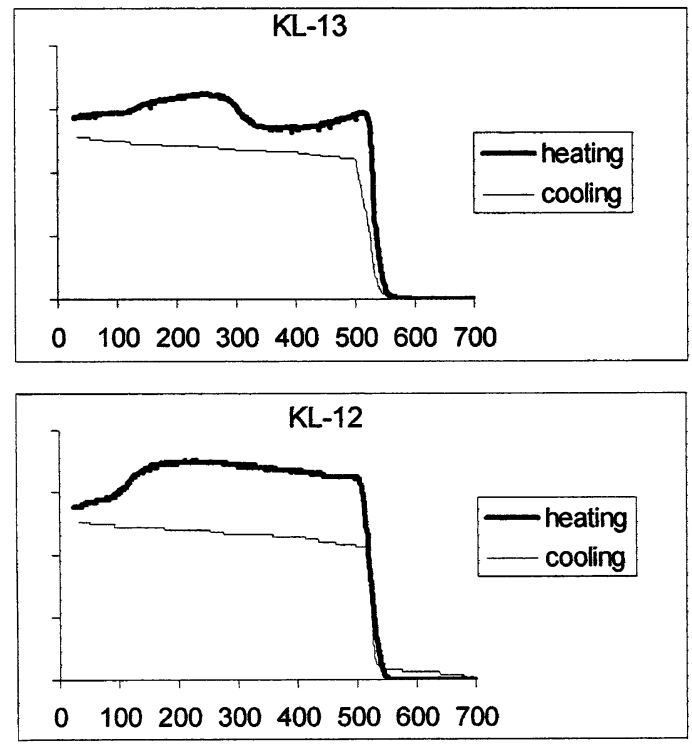

Fig. 4. Low field bulk magnetic susceptibility vs. temperature (in ${ }^{\circ} \mathrm{C}$ ) for the representative samples of two sites KL-12 and KL-13.

(Fig. 5). In the first group of samples (Type-I) there is a change in the slope of the curve at $200 \mathrm{mT}$ (Fig. 5(a)) and saturation is almost attained at $200 \mathrm{mT}$. In the demagnetization curve there is major decrease in the intensity of IRM up to $300^{\circ} \mathrm{C}$ followed by gradual decrease until complete demagnetization at about $600^{\circ} \mathrm{C}$. The second group (Type-II) has low coercive remanent carriers as shown by the saturation of 


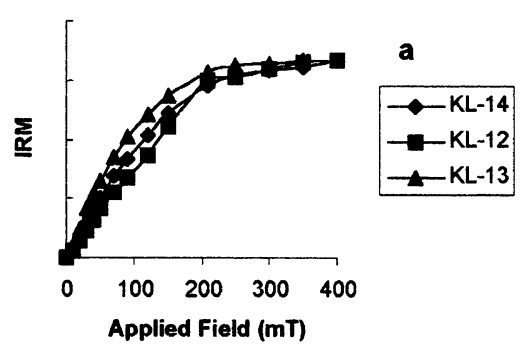

$\mathrm{KL}-8$

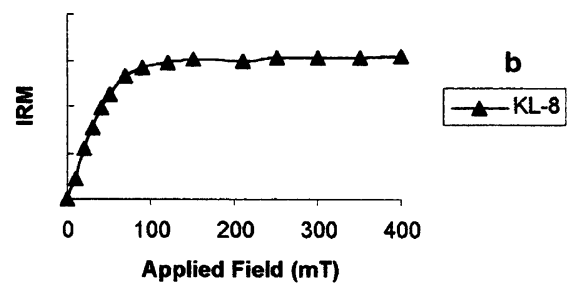

KL-24
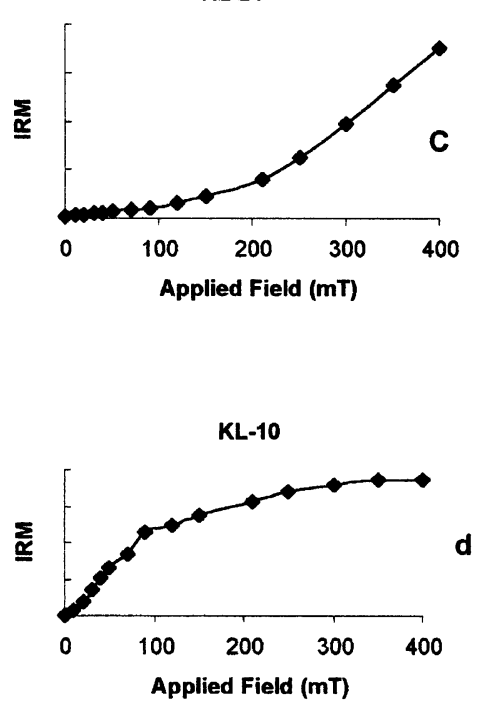

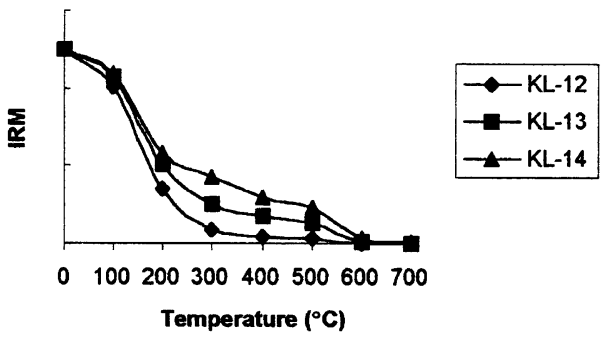

KL-8

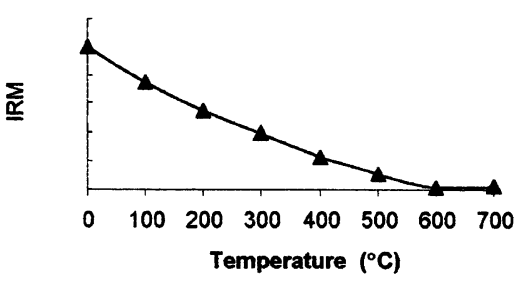

KL-24
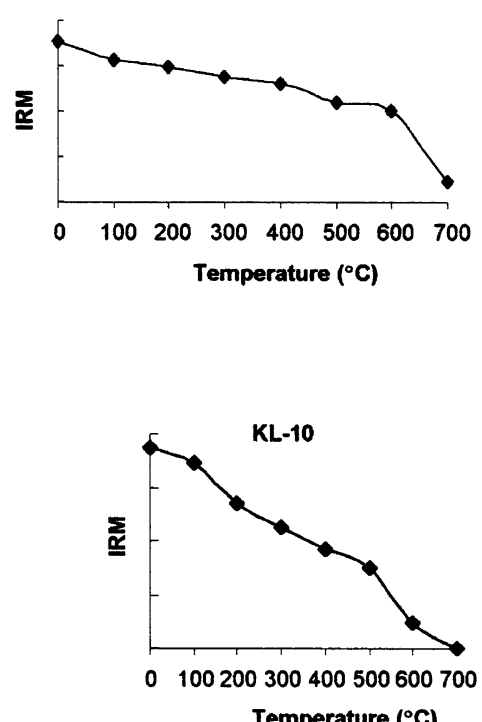

Fig. 5. IRM acquisition curves (left side) followed by thermal demagnetization (right side).

isothermal remanent magnetization (SIRM) at $100 \mathrm{mT}$. Stepwise thermal demagnetization of induced IRM reveals single blocking temperature of about $600^{\circ} \mathrm{C}$ (Fig. 5(b)). The samples from site KL-24 exhibit hard magnetic behavior during acquisition of IRM (Type-III; Fig. 5(c)) and higher unblocking temperature (about $700^{\circ} \mathrm{C}$ ). Two magnetic phases can be inferred in some samples (Fig. 5(d)) from linear increase in IRM up to $100 \mathrm{mT}$ and undersaturation up to $400 \mathrm{mT}$ (TypeIV). These two magnetic phases can also be distinguished in demagnetization curve having significant decrease in intensity of IRM at $600^{\circ} \mathrm{C}$ with its complete demagnetization at $700^{\circ} \mathrm{C}$.

In the curves of Type-I the drop of IRM at about $300^{\circ} \mathrm{C}$ may be due to the presence of maghemite or titanomaghemite and complete removal of induced IRM about blocking temperature of magnetite indicating that magnetite is also present as remanent carrier. The possibility of pyrrhotite which has almost the same unblocking temperature $325^{\circ} \mathrm{C}$ as of maghemite is ruled out because pyrrhotite has high coercivity up to $0.5-1 \mathrm{~T}$ (O'Reilly, 1984) but saturation is attained at about $200 \mathrm{mT}$ in our case (Fig. 5(a)). In the Type-II curves (Fig. 5(b)) the low saturation magnetic field and drop of induced IRM to zero at about blocking temperature of magnetite indicating magnetite as the only magnetic carrier. In the case of a sample from the site KL-24 (Fig. 5(c)), the high coercivity pattern of IRM and the gradual decrease of intensity of induced IRM without exhibiting unblocking temperatures lower than that of hematite provide the evidence that hematite is the only magnetic carrier in the samples of this site. The sample belonging to Type-IV curves has both magnetite and hematite as both low and high coercivity spectra are noted along with blocking temperatures of magnetite and 
Table 1. Description of blocking temperatures range $\left({ }^{\circ} \mathrm{C}\right)$ for Comp-1, Comp-2 and ChRM along with remanent magnetic carriers. See detail of magnetic mineralogy in the text. ? in the mineralogy column means that this is guessed mineralogy only on the bases of unblocking temperature of thermal demagnetization, while others are interpreted after IRM analysis.

\begin{tabular}{|c|c|c|c|c|}
\hline Site & Comp-1 & Comp-2 & ChRM & Remanent magnetic carriers \\
\hline KL-2 & & & $540-600$ & Titanohematite \\
\hline KL-3 & $20-300$ & $400-560$ & $560-600$ & Maghemite, Ti-poor titanomagnetite, Titanohematite \\
\hline KL-4 & & & $545-600$ & Titanohematite \\
\hline KL-5 & & & $540-600$ & Titanohematite \\
\hline KL-6 & & & $545-600$ & Titanohematite \\
\hline KL-7 & & & $530-580$ & Magnetite \\
\hline KL-8 & $20-200$ & & & Magnetite \\
\hline KL-9 & $20-200$ & & & Magnetite? \\
\hline KL-10 & $100-400$ & & $525-660$ & Hematite \\
\hline KL-12 & & & $400-580$ & Maghemite and Magnetite \\
\hline KL-13 & $20-200$ & & $550-580$ & Maghemite and Magnetite \\
\hline KL-14 & $20-300$ & & & Maghemite and Magnetite \\
\hline KL-15 & & & $530-580$ & Magnetite? \\
\hline KL-18 & & & $640-680$ & Hematite? \\
\hline KL-23 & $20-350$ & & $530-580$ & Maghemite? and Magnetite? \\
\hline KL-24 & & & $655-690$ & Hematite \\
\hline
\end{tabular}

hematite (Fig. 5(d)). Hence these volcanics host a vast variety of magnetic minerals such as maghemite, magnetite, and hematite.

\section{Petrography}

To determine the petrographic relationship of ferromagnetic minerals optical microscopic study of these volcanics was done. The primary rock forming minerals, which are phenocryst, are plagioclase, K-feldspar, quartz, pyroxene. Quartz, plagioclase and K-feldspar phenocrysts are partly replaced by fine-grained quartz, sericite, chlorite, calcite, epidote, and zeolite. The opaque minerals are altered to Fe-oxides and Fe-hydrate (Plate 1). The ground mass has been mostly replaced by secondary minerals such as quartz, sericite, chlorite, epidote, and zeolite. Secondary minerals such as zeolite and chlorite may be indicators of hydrothermal alterations in these volcanics (Ade-Hall et al., 1971; Cas and Wright, 1987).

\section{Paleomagnetic Results}

Remanent magnetization was measured using Natsuhara/ SMD-88 and Schonstedt SSM-1A spinner magnetometers. Stepwise thermal demagnetization (THD) was performed and demagnetization results are plotted as orthogonal vector diagrams (Zijderveld, 1967). NRM components were obtained by principal component analyses (Kirschvink, 1980) and mean directions are calculated by using fisher statistics (Fisher, 1953). In most of cases two components were identified, the first component (Comp-1) is mostly unblocked up to $300^{\circ} \mathrm{C}$ (Fig. 6(a)) but in some cases it is unblocked at higher temperatures even up to $400^{\circ} \mathrm{C}$ (Fig. 6(b)). In samples of
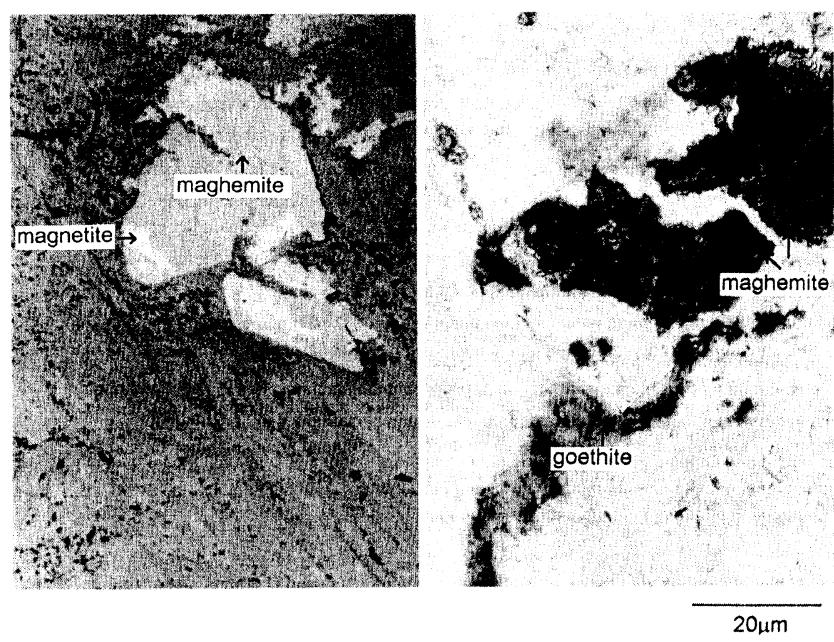

Plate 1. Photomicrograph of a representative sample showing a) Magnetite-maghemite (reflective light) b) Goethite and maghemite (transparent light).

three sites (KL-9, KL-8, and KL-14) only Comp-1 could be observed, at high temperatures remanence intensity becomes very weak to be measured by the used spinner magnetometer. The characteristic remanent magnetization (ChRM) component has rather shallow downward and upward inclinations with scattered declinations in geographic coordinates (Figs. 6 and 7). The unblocking temperature of ChRM is variable for each site (Table 1). In three samples of site KL-3 an intermediate component (Comp-2) is observed from $300^{\circ} \mathrm{C}$ to $560^{\circ} \mathrm{C}$ 


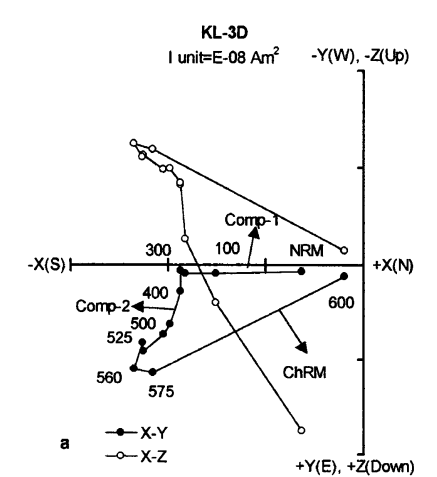

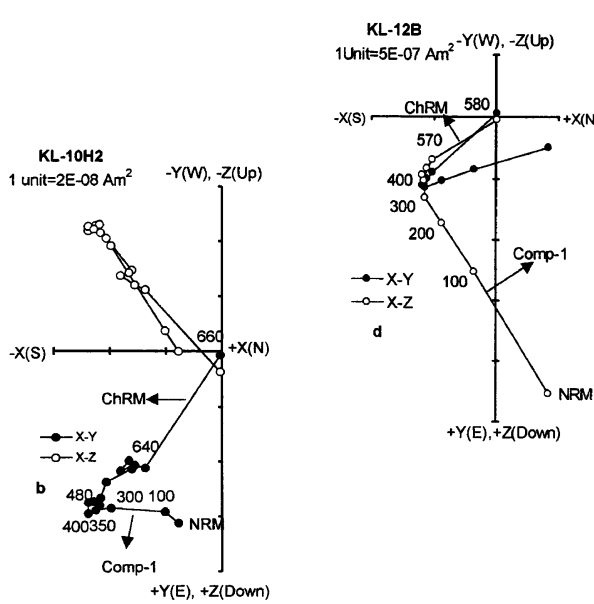
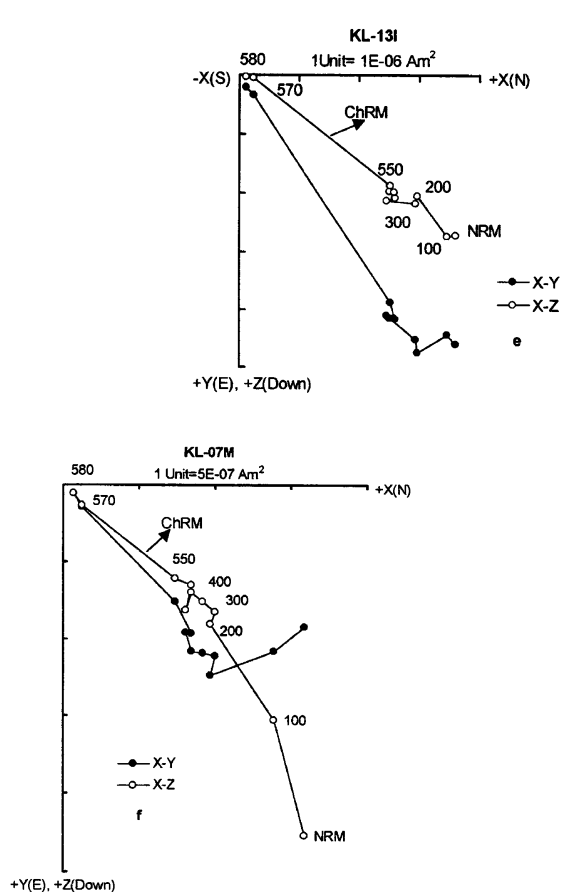
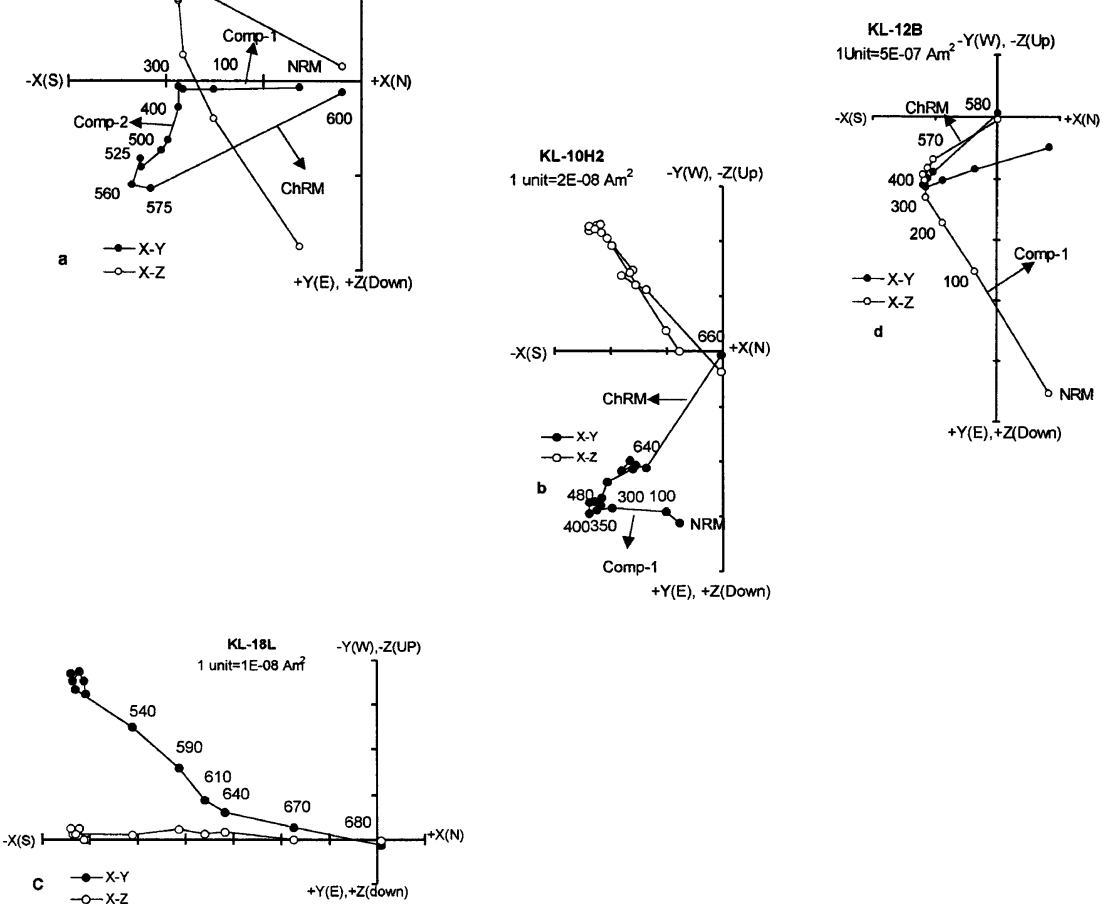

Fig. 6. Zijderveld plots of progressive thermal demagnetization of samples a) KL-3D b) KL-10H2, c) KL-18L, d) KL-12B, e) KL-13I, and f) KL-07M.

having westward directions with moderate positive inclinations (Table 2; Fig. 6(a)). Data of site KL-22 is not used for the calculation of mean direction because of large $\alpha-95$ $\left(33.3^{\circ}\right)$ and data of site KL-6 is excluded because of too few number of samples (only two). The unblocking temperatures of the observed components for all sites are listed in Table 1.

In the case of ChRM, the site mean directions before the application of structure correction show mostly moderate to shallow downward and upward inclinations, where as declinations range from northeasterly to south-southwesterly. Upon tilt correction by simple rotations around strikes, inclinations show much less uniformity, where as declinations maintains their large range of scattering (Table 2, Fig. 7).

There is another possibility of synfolding magnetizations, this can be checked by performing incremental fold test. In this test, change in clustering of paleomagnetic data as function of percentage of unfolding is determined (McElhinny, 1964; Watson and Enkin, 1993; McFadden, 1998). In our case this conventional fold test is not applicable as declinations are dispersed and Inclinations are showing more or less uniformity in geographic coordinates. This can be happened, when magnetizations have undergone variable amounts of vertical-axis rotations without changing the dips of the rocks. To deal with this problem inclination only fold test was devised (McFadden and Reid, 1982; Enkin and Watson, 1996). Enkin and Watson (1996) inclination only fold test, is based on the assumption that population of directions of magnetization is most tightly grouped in orientation in which magnetizations were acquired. This method is parameter estimation problem by unfolding the rocks to find the maximum clustering. The percentage of untilting that produces maximum precision is sorted. The best estimate of optimum untilting is median (50 percentile), while the lower and upper 95 per cent confidence limits are 2.5 and 97.5 percentile values. If confidence limits include 0 per cent or 100 per cent, then magnetization will be post folding or pre-folding respectively, otherwise syn-folding magnetization.

In present case ChRM directions are scattered having upward and downward inclinations in geographic coordinates. Before proceeding for the calculation of mean direction it is important to decide about the polarity of directions. As it is well established that since 65-60Ma the northern part of Indian continent was at equatorial to low northern latitudes (Klootwijk et al., 1992). Therefore the magnetization acquired at or after the time of formation of volcanics (age of volcanics $55 \pm 2 \mathrm{Ma}$ ) must indicate northern hemisphere direction. Hence all negative inclinations indicate the acquisition of magnetization in northern hemisphere during reverse polarity. In order to calculate correct mean we have to convert all directions with negative inclination to antipodal. The data can be interpreted in two ways, either all ChRM directions were acquired in same reverse polarity time (referred as Case-I hereafter) with shallow upward and downward inclinations or ChRM directions having down ward inclinations were acquired at the time of normal polarity, contrary to rest of ChRM directions and then suffered high angle rotations (Case-II). We will perform inclination only fold test and calculate inclination only mean by the above two mentioned 

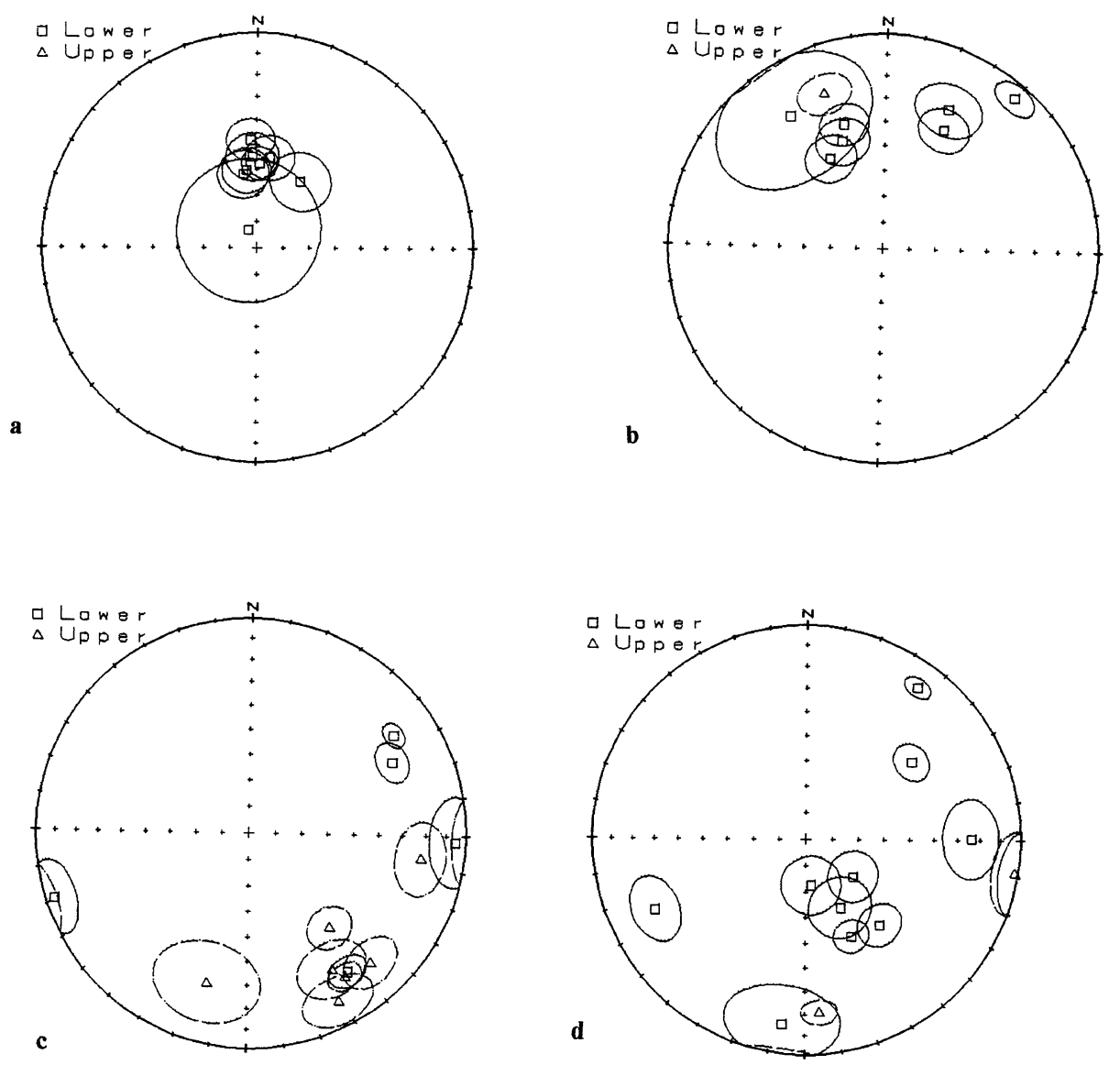

Fig. 7. Equal area projection a) of Comp-1 before structure correction, b) of Comp-1 after structure correction, c) of ChRM before structure correction and d) of ChRM after structure correction.

options.

In Case-I i.e., if these directions were acquired in reverse polarity then best optimum untilting is $37.2 \%$ with lower and upper confidence limits $28.3 \%$ and $43.8 \%$ respectively (Table 3$)$. The mean inclination in this case is $-8.9^{\circ}$. The calculated mean paleolatitude for the Case-I is $4.5 \pm 6^{\circ} \mathrm{S}(37 \%$ of untilting). The mean is yielding southern latitude position as compared to primary mid Cretaceous red beds' paleolatitude of the Kohistan $\operatorname{arc}\left(2.2^{\circ} \mathrm{S}\right.$ and $1.1^{\circ} \mathrm{N}$; from Zaman and Torri, 1999). Keeping in mind the age of the volcanics (55 $\pm 2 \mathrm{Ma})$, this southern paleolatitude of these volcanics with respect to mid Cretaceous red beds data seems to be odd at the time of rapid northward convergence of Indian continent. Hence calculated mean paleolatitude for Case-I is biased towards southern latitudinal position because of improper discrimination of components or polarities. As Case-I is very much unlikely in the light of previously well reported primary magnetizations of the area, it is not considered further.

Assuming that five sites (KL-7, KL-12, KL-13, KL-15 and KL-23) sites having shallow to moderate positive inclination acquired ChRM in normal polarity and samples of all other sites having negative inclinations acquired ChRM during reverse polarity (i.e. Case-II). Then according to Enkin and Watson (1996) syn-folding inclination only fold test they are post-folding magnetizations (Table 3). Mean Inclination for positive ones is 17.1, while for negative ones is -24.6. There is no significant difference of best estimated untilting by applying McFadden and Reid (1982) method, it is $40 \%$ for Case-I and for Case-II 10\% for downward inclinations and $0 \%$ for upward inclinations.

There is no distinction in plotting of mean direction of characteristic magnetizations of sites on the basis of mineralogy. We cannot group directions of sites depending upon the remanent carrier of their samples (magnetite or hematite). But if we see the only inclinations of ChRM, it is observable that all positive mean inclinations in geographic coordinates are carried by magnetite (in sites KL-7, KL-12, KL-13, KL15 and KL-23), whereas as all negative mean inclinations are carried by hematite or Ti-poor hematite (Table 1; Table 2). This correlation in magnetic mineralogy and downward and upward inclinations may account for the different remagnetization processes at different polarity times. The Comp- 2 that is observed in three samples of site KL-3 also has positive inclination and unblocking temperature of Ti-poor magnetite $\left(560^{\circ} \mathrm{C}\right)$. Therefore we also included this direction for the calculation of the mean for characteristic remanent component carried by magnetite. In this case (Case-II) Inclination only mean is calculated separately for the sites having different magnetic carrier for ChRM and different polarities (Table 3). 
Table 2. $\mathrm{N} / \mathrm{n}$ is number of samples processed / number of samples in which specific components are observed. Dg, Ig are declination and inclination in geographic coordinates. Ds and Is are declination and inclination in stratigraphic coordinates. $\mathrm{k}$ and $\alpha-95$ are correspond to geographic coordinates. Bedding is expressed in strike/dip (using right hand rule). The sites marked with $\left(^{*}\right)$ are not used for mean calculation.

\begin{tabular}{|c|c|c|c|c|c|c|c|c|}
\hline \multicolumn{9}{|c|}{ Mean directions of Comp-1 } \\
\hline Site & $\mathrm{N} / \mathrm{n}$ & $\operatorname{Dg}\left({ }^{\circ}\right)$ & $\operatorname{Ig}\left({ }^{\circ}\right)$ & $\mathrm{k}$ & $\alpha 95\left(^{\circ}\right)$ & $\operatorname{Ds}\left({ }^{\circ}\right)$ & $\operatorname{Is}\left({ }^{\circ}\right)$ & Bedding \\
\hline KL-10 & $10 / 8$ & 1.9 & 57.6 & 71.8 & 6.6 & 39.9 & 7.5 & $340 / 68$ \\
\hline KL-13 & $9 / 3$ & 335.9 & 82.5 & 21.3 & 27.4 & 324.0 & 25.7 & $232 / 57$ \\
\hline KL-14 & $12 / 12$ & 8.3 & 54.9 & 24.4 & 9.0 & 26.0 & 37.7 & $332 / 20$ \\
\hline KL-22 & $6 / 5$ & 33.3 & 59.6 & 46.0 & 11.4 & 24.1 & 28.8 & $282 / 32$ \\
\hline KL-23 & $6 / 6$ & 349.6 & 61.3 & 52.0 & 9.4 & 328.8 & 49.8 & $205 / 20$ \\
\hline KL-9 & $8 / 4$ & 356.7 & 48.0 & 113.8 & 8.6 & 341.5 & 39.1 & $198 / 18$ \\
\hline KL-8 & $14 / 7$ & 357.2 & 54.8 & 41.8 & 9.6 & 338.3 & 45.5 & $198 / 18$ \\
\hline KL-3 & $5 / 5$ & 352.4 & 60.0 & 74.6 & 8.9 & 338.0 & -23.7 & $232 / 88$ \\
\hline Mean & $\mathrm{N}=8$ & $\begin{array}{c}1.6 \\
\left(\alpha 95=8.6^{\circ}\right.\end{array}$ & $\begin{array}{c}60.5 \\
k=42.8)\end{array}$ & & & $\begin{array}{c}356.3 \\
\left(\alpha 95=26.3^{\circ}\right.\end{array}$ & $\begin{array}{c}30.1 \\
k=5.4)\end{array}$ & \\
\hline
\end{tabular}

\begin{tabular}{|c|c|c|c|c|c|c|c|c|}
\hline \multicolumn{9}{|c|}{ Mean directions of Comp-2 } \\
\hline Site & $\mathrm{N} / \mathrm{n}$ & $\operatorname{Dg}\left({ }^{\circ}\right)$ & $\operatorname{Ig}\left({ }^{\circ}\right)$ & $\mathrm{k}$ & $\alpha 95\left(^{\circ}\right)$ & $\operatorname{Ds}\left({ }^{\circ}\right)$ & $\operatorname{Is}\left({ }^{\circ}\right)$ & Bedding \\
\hline KL-3 & $5 / 3$ & 296.0 & 22.6 & 45.4 & 18.5 & 277.6 & -54.7 & $232 / 88$ \\
\hline \multicolumn{9}{|c|}{ Mean directions for ChRM } \\
\hline Site & $\mathrm{N} / \mathrm{n}$ & $\operatorname{Dg}\left({ }^{\circ}\right)$ & $\operatorname{Ig}\left({ }^{\circ}\right)$ & $\operatorname{Ds}\left({ }^{\circ}\right)$ & $\operatorname{Is}\left({ }^{\circ}\right)$ & $\mathrm{k}$ & $\alpha 95\left(^{\circ}\right)$ & Bedding \\
\hline KL-7 & $6 / 6$ & 60.6 & 25.2 & 52.2 & 38.9 & 96.2 & 6.9 & $198 / 18$ \\
\hline KL-10 & $16 / 16$ & 145.6 & -21.1 & 175.2 & -20.5 & 42.3 & 5.7 & $340 / 68$ \\
\hline KL-12 & $11 / 9$ & 143.8 & 22.3 & 154.5 & 48.7 & 108.0 & 6.5 & $210 / 30$ \\
\hline KL-13 & $9 / 9$ & 54.7 & 20.5 & 35.9 & 13.1 & 144.3 & 4.3 & $232 / 57$ \\
\hline KL-15 & $8 / 8$ & 250.8 & 4.7 & 244.8 & 23.3 & 27.4 & 10.8 & $30 / 30$ \\
\hline KL-18 & $13 / 13$ & 195.0 & -28.1 & 187.1 & 14.7 & 6.5 & 17.6 & $225 / 70$ \\
\hline KL-23 & $6 / 6$ & 91.8 & 5.4 & 89.6 & 23.7 & 30.9 & 12.7 & $205 / 20$ \\
\hline KL-24 & $6 / 4$ & 97.9 & -21.0 & 99.1 & -1.8 & 63.5 & 11.6 & $205 / 20$ \\
\hline KL-2 & $5 / 5$ & 136.3 & -18.7 & 128.0 & 67.1 & 56.6 & 10.3 & $232 / 88$ \\
\hline KL-3 & $6 / 6$ & 151.3 & -12.8 & 173.4 & 72.3 & 38.0 & 11.0 & $232 / 88$ \\
\hline KL-4 & $5 / 5$ & 148.0 & -26.7 & 153.0 & 60.7 & 33.4 & 11.8 & $232 / 88$ \\
\hline KL-5 & $5 / 5$ & 139.0 & -41.7 & 138.8 & 46.2 & 88.3 & 8.2 & $232 / 88$ \\
\hline KL-6* & $2 / 2$ & 100.6 & -43.3 & 107.7 & 31.4 & & & $232 / 88$ \\
\hline KL-22* & $6 / 6$ & 261.0 & 19.6 & 274.9 & 27.6 & 5.2 & 33.3 & $282 / 32$ \\
\hline
\end{tabular}

Table 3. Estimated degree of untilting giving optimum concentration of magnetic directions (1000 trials) for inclination only by Enkin and Watson (1996) method. Mean inclination and corresponding $\alpha-95$ is noted for best estimate degree of untilting i.e. at $50 \%$-ile. $\lambda \pm \Delta \lambda$ is paleolatitude with confidence limits.

\begin{tabular}{|c|c|c|c|c|c|c|}
\hline & $2.5 \%$-ile & $50 \%$-ile & $97.5 \%$-ile & Mean inclination & $\alpha-95$ & $\lambda \pm \Delta \lambda$ \\
\hline Case-I & 28.7 & 37.2 & 43.8 & -8.9 & 11.7 & $4.5 \pm 6^{\circ} \mathrm{S}$ \\
\hline \multicolumn{7}{|l|}{ Case-II } \\
\hline For + ive inclination ${ }^{\dagger}$ & -2.5 & 7.7 & 18.7 & 17.1 & 8.3 & $9 \pm 4^{\circ} \mathrm{N}$ \\
\hline For -ive inclination & -2.6 & 3.4 & 9.8 & $-24.6^{\ddagger}$ & 7.4 & $13 \pm 4^{\circ} \mathrm{N}$ \\
\hline
\end{tabular}

${ }^{\dagger}$ Comp-2 of site KL-3 is also included as it is yielding inclination of the similar range.

\$ Mean without converting to normal polarity. 


\section{Discussion}

\subsection{Remanent carriers of NRM}

Present paleomagnetic study demonstrates that the natural remanent magnetization (NRM) of Utror Volcanic Formation is mostly composed of two components, a third component was only observed in one site as discussed above (Table 2). The Comp-1 is unblocked at lower temperatures. In the samples of sites KL-8 and KL-9 Comp- 1 is revealed up to $200^{\circ} \mathrm{C}$ after this temperature the remanence intensity becomes very weak to be measured by the used spinner magnetometer. The major magnetic carrier in the case of samples of the site KL-8 is magnetite as indicated by stepwise thermal demagnetization of IRM acquired sample (Fig. 5(b)). Thus in the samples of the site KL- 8 Comp- 1 may be carried by magnetite as viscous magnetization. Whereas in samples of the sites KL-13 and $\mathrm{KL}-14$, the Comp- 1 is carried up to $300^{\circ} \mathrm{C}$ and in the case of samples of the site KL-14 only Comp-1 is encountered (Table 1). The susceptibility measurements as a function of temperature (Fig. 4) and IRM experiments show the presence of titanomaghemite or maghemite in samples of sites KL-13 and KL-14 (Fig. 5). Therefore maghemite or titanomaghemite may be the carriers of the Comp-1 in samples of these sites. Samples from the site KL-23 show the unblocking temperature of Comp- 1 up to about $350^{\circ} \mathrm{C}$ (Table 1), the magnetic carrier in this case may also be maghemite. Samples of site KL-10 show Comp-1 up to $400^{\circ} \mathrm{C}$ (Fig. 6(b)). The IRM analysis and its stepwise thermal demagnetization indicate the presence of magnetite and hematite (Fig. 5(d)). Hence the Comp-1 in this case is perhaps viscous magnetization acquired by these two mineral assemblages. By combining the results of all magnetic techniques, it can be inferred that Comp- 1 is carried by maghemite or titanomaghemite and in samples of some sites it is VRM maintained by magnetite or hematite grains.

There is wide range of unblocking temperatures for ChRM (Table 1). In samples of five sites (KL-7, KL-12, KL-13, $\mathrm{KL}-15$ and $\mathrm{KL}-23$ ) $\mathrm{ChRM}$ was unblocked at about $580^{\circ} \mathrm{C}$, Whereas in samples of other sites the unblocking temperature varies from $600-680^{\circ} \mathrm{C}$ (Table 1 ). In the case of ChRM of samples of sites KL-2, 3, 4, and 5 unblocking temperature is up to $600^{\circ} \mathrm{C}$, which may be due to the presence of titanohematite. The presence of high coercivity minerals in samples of these sites is inferred from undersaturation of IRM even up to $2.5 \mathrm{~T}$ (Ahmad and Yoshida, 1997). The samples of the site KL-10 exhibits unblocking temperature up to $660^{\circ} \mathrm{C}(\mathrm{Ta}-$ ble 1; Fig. 6(b)). Stepwise thermal demagnetization of IRM reveals magnetite and hematite as magnetic carriers in samples of above mentioned site (Fig. 5(d)). Samples from sites $\mathrm{KL}-7, \mathrm{KL}-12, \mathrm{KL}-13, \mathrm{KL}-15$, and $\mathrm{KL}-23$ indicate $580^{\circ} \mathrm{C}$ as blocking temperature (Table 1). Samples from the sites KL-12 and KL-13 show the presence of magnetite in IRM acquisition experiment (Table 1, Fig. 5). On the other hand the ChRM in samples of the sites KL-24 was completely demagnetized at unblocking temperature of hematite (Table 1). The presence of high coercivity mineral in site KL-24's sample is confirmed by IRM analysis. The remanent carriers of ChRM vary in samples of individual sites and these are hematite, Ti-poor hematite and magnetite.

As discussed in optical microscopic study that these volcanics are highly altered and the presence of zeolite indicate that they may have suffered some hydrothermal alterations. Alteration products in these volcanics indicate that important secondary processes are hydration and oxidation (Sullivan et al., 1993). Secondary Fe-oxide minerals were also observed in these volcanics by optical studies. Inclination only fold test demonstrates that ChRM are not of primary nature. Therefore magnetic carriers of ChRM are of secondary nature, which may be produced during some alterations (may be hydrothermal) after the formation of the volcanics.

The mineralogical situation of ChRM is somewhat complex. In samples of some sites ChRM is carried by magnetite, while in others by hematite or Ti-poor hematite, and these sites lie very close to each other. This spatial distribution of different magnetic minerals may be due to variable effect of alterations depending upon the local environmental conditions (Gautam, 1989). These volcanics contain two metamorphic assemblages. The first assemblage, which is dominant, corresponds to greenschist facies and the other assemblage, which locally overprints the green schist facies, corresponds to epidote amphibolite facies (Shah and Shervais, 1999). Shah and Shervais (1999) interpreted minimum metamorphic temperature about $300^{\circ} \mathrm{C}$ and maximum temperature about $500^{\circ} \mathrm{C}$. The overprinting of the second assemblage on local scale is explained by higher temperature associated with hydrothermal fluid flow along local shear zones, which act as conduits for the circulating fluids (Shah and Shervais, 1999). Hence alteration processes have variable effect on these volcanics and may produce different magnetic minerals depending upon local environmental conditions. The spatially inhomogeneous distribution of magnetic minerals can also be explained by the inhomogeneous distribution of these two metamorphic assemblages. The existence of two distinctive phases of metamorphism, one is overprinting the other locally, supports the Case-II. In Case-II, we assume that ChRM of magnetite and hematite were acquired in two different polarity times. The correlation in magnetic mineralogy and downward and upward inclinations may be due to the remagnetizations at different polarity times. Therefore magnetite and hematite may be formed chemically due to the two phases of above-mentioned metamorphism at different times.

The possibility of thermally acquired secondary remanent magnetization is ruled out on the basis of maximum rise in temperature $\left(500^{\circ} \mathrm{C}\right)$, which is much lower than the curie temperature of observed magnetic mineral assemblages. The other type of remagnetization is thermoviscous remanent magnetization (TVRM) which can be acquired as secondary remanent magnetizations at elevated temperatures. But in these volcanics high temperature condition did not prevail for significant geological time period, as zircon (closure temperature $175^{\circ} \mathrm{C}$ ) fission track data yields about $35.9 \pm 2.4$ Ma age (Zeitler, 1985, sample no. SW-11). According to Pullaiah et $a l .$, (1975) curves there is no possibility of complete remagnetization in the form of TVRM by magnetite (laboratory unblocking temperature $=580^{\circ} \mathrm{C}$ ) and hematite assemblage of grains (laboratory unblocking temperature $600 \sim 680^{\circ} \mathrm{C}$ ) at the above mentioned low temperature. The remagnetization may occurred as thermo chemical remanent magnetization (TCRM) during some hydrothermal activity related with two stages of alterations as discussed above. 
There is not much difference in terms of paleolatitudes of two ChRM directions carried by magnetite and hematite. The mean paleolatitude for magnetite's ChRM is $9 \pm 4^{\circ} \mathrm{N}$ whereas that of ChRM carried by hematite is $13 \pm 4^{\circ} \mathrm{N}$. Error limits of these two mean paleolatitudes overlap with each other. If these two mineral assemblages represent two different phase of alterations, then both phases must have close temporal relationship as the north ward movement of Indian continent was quiet rapid at low northern latitudes (Klootwijk et al., 1992). Magnetite may be formed somewhat earlier than hematite and Ti-poor hematite. There are questions related with this type interpretation i.e. why area has partly suffered by these two phases of alterations? Why we have encountered both of these mineral assemblages in samples of only one site (KL-3)? Why in samples of some sites ChRM are carried by magnetite and in others by hematite assemblages and these sites lie close to each other? Possibility of this type situation is not remote as hydrothermal alterations may occur in close spatial and temporal relationship. Where these occur resultant mineralogy may be complex (Cas and Wright, 1987: pp. 417). This type inhomogeneous distribution of remanent components is also reported in Aulis volcanics of lesser Himalaya in Nepal (Gautam, 1989).

\subsection{Age of natural remanent magnetizations}

The knowledge of the timing of acquisition of various magnetization components is crucial for their interpretation. The mean of Comp-1 is close to the recent field at sampling locality $(\mathrm{Dec}=2$, Inc=53.0). According to inclination only fold test ChRM is not of primary nature and remagnetization may be TCRM (as discussed earlier).

In Case-II there is not much difference in terms of paleolatitude calculated for ChRM carried by magnetite $\left(9 \pm 4^{\circ} \mathrm{N}\right)$ and hematite $\left(13 \pm 4^{\circ} \mathrm{N}\right)$, but correlation in magnetic mineralogy and downward and upward inclinations may be due to different remagnetization phases at different magnetic polarity. According to inclination only fold test they are postfolding magnetizations. The paleolatitudes calculated for the Case-II are well in agreement with the suit of secondary magnetizations, acquired at equatorial to low northern latitudes, at the time of India-Eurasia collision (Klootwijk et al., 1979; Klootwijk et al., 1984; Klootwijk et al., 1994; Zaman and Torii, 1999). The acquisition of these secondary magnetizations is attributed to the chemically active orogenic fluids at the time of collision (Zaman and Torii, 1999). The timing of acquisition and evolution of these secondary magnetizations is matter of extensive debate and most of these magnetizations do not have any independent age control. The abovereferred studies reported range of paleolatitudes of secondary magnetizations related with the collision $\left(0\right.$ to $\left.10^{\circ} \mathrm{N}\right)$. This is somewhat large range of paleolatitudes of secondary magnetizations because of complexities related with collision. Collision is a complex event that lasts for some time and related with number of tectonic and metamorphic processes (Le Fort, 1996). In the final stage of convergence of Indian continent (60-45 Ma), when some of the water rich sediments were dragged along the subduction zone, high volume of magma emplaced in the Transhimalaya (Debon et al., 1986; Le Fort, 1996). The wide spread secondary magnetizations at the time of collision may be because of circulation of the fluids related with the emplacement of this high volume magma.
Table 4. Calculated paleolatitudes from Indian APWP (Klootwijk et al., 1991 ) at site $35.5^{\circ} \mathrm{N}, 72.5^{\circ} \mathrm{E}$.

\begin{tabular}{ll}
\hline Age Ma & Paleolatitude \\
\hline 20 & $27.3^{\circ} \mathrm{N}$ \\
25 & $25.7^{\circ} \mathrm{N}$ \\
30 & $24.1^{\circ} \mathrm{N}$ \\
35 & $22.4^{\circ} \mathrm{N}$ \\
40 & $20.5^{\circ} \mathrm{N}$ \\
45 & $18.4^{\circ} \mathrm{N}$ \\
50 & $16.3^{\circ} \mathrm{N}$ \\
55 & $14.2^{\circ} \mathrm{N}$ \\
60 & $5.8^{\circ} \mathrm{N}$ \\
65 & $2.6^{\circ} \mathrm{S}$ \\
\hline
\end{tabular}

In the Ladakh area, which is east of Nanga Parbat Syntaxis, secondary magnetizations yield low northern paleolatitudes $\left(7-10^{\circ} \mathrm{N}\right)$ with closure of isotopic systems at about $50 \mathrm{Ma}$ (Klootwijk et al., 1979). These paleolatitudes are comparable with the paleolatitudes from the present study. Moreover indirectly age can be assigned to these secondary magnetizations by comparing northward-progressing paleolatitude of Indian continent with paleolatitudes of secondary magnetizations. Klootwijk et al. (1991 and 1992) established new paleolatitude control on India's northward motion during last $80 \mathrm{Ma}$, obtained from ODP Leg 121 studies on Ninetyeast Ridge. In the absence of any radiometric age control for these post folding secondary magnetizations, these can be dated only indirectly through comparison of their paleolatitudes with the paleolatitudinal control on India's northward movement.

The comparison of mean paleolatitude of ChRM carried by magnetite and by hematite with calculated paleolatitude from Indian APWP for the area $\left(35.5^{\circ} \mathrm{N}, 72.5^{\circ} \mathrm{E}\right)$, assuming no relative motion between Kohistan and the Indian Shield, shows that paleolatitude for ChRM carried by magnetite is correlated with 60-55Ma segment of APWP and for ChRM carried by hematite is correlated with $55-50 \mathrm{Ma}$ (Table 4) (Klootwijk et al., 1991). The error on the mean of these two magnetizations led to time uncertainties from $60-45 \mathrm{Ma}$, when compared to APWP. The age of the volcanics is $55 \pm 2 \mathrm{Ma}$. Therefore post folding secondary magnetizations must be younger than $55 \pm 2 \mathrm{Ma}$. Thus according to uncertainty limits, these secondary magnetizations may have been acquired between 55 45 Ma. This is a period ranging from completion of the India Eurasia suture to final emplacement of collision related magma in Himalayan region (60-45Ma from Debon et al., 1986). The completion of the suture has been interpreted at about $55 \mathrm{Ma}$ by using paleomagnetic data (Klootwijk et al., 1992). Moreover fauna data from Baraul Slate Formation indicates marine conditions were prevailing in the area up to $55 \mathrm{Ma}$. Thus collision may have been completed some time after $55 \mathrm{Ma}$ in the area. From inclination only fold test 
it is clear that the ChRM are post folding magnetizations. According to previously reported paleomagnetic data of Indian continent and Himalayan region, it has been inferred that after completion of suture (at $55 \mathrm{Ma}$ ), indentation phase started and Indian continent impinged in to northern territory more than $2000 \mathrm{~km}$ during early Eocence and Oligocene (Klootwijk et al., 1985). The folding of these volcanics may be the result of initial indentation phase. Thus these secondary magnetizations may be acquired after the completion of the suture. Stage-2 (48-45 Ma) granites have also been reported in the north of these volcanics (Fig. 2). Unfortunately paleomagnetic data from these granites may not be useful because of lack of structure control. Though granites and the volcanics have thrusted contact, but thrust has locally reworked intrusive contact (Sullivan et al., 1993). Therefore these two units would not have been too far when the granites were intruded. Moreover we are not interpreting that these secondary magnetizations are thermo remanent magnetization which were acquired from direct heating. In this scenario these secondary magnetizations may attribute to wide spread circulation of hydrothermal fluids related with the emplacement of stage-2 granite at about 48-45 Ma. Hence the possibility of acquisition of remanent magnetizations at the time of granitic intrusion cannot be ruled out. In this comparison of paleolatitudes with paleolatitudes of Indian APWP, north-south crustal shortening of $470 \mathrm{~km}$ (about $4^{\circ}$ ) since Eocene with in Indian continent (Coward et al., 1987), south of the arc, have been ignored. Part of this shortening must have been taken place after the acquisition of remanent magnetizations and simple comparison of two paleolatitudes may yield somewhat younger ages. Even if whole shortening would have been occurred after acquisition of remanent magnetizations, then total error will be of the order of $4^{\circ}$, which lies with in the uncertainty limits of calculated mean paleolatitudes. Thus on the basis of uncertainties, range of age can be assigned to these secondary magnetizations which is 55-45 Ma. This is ranging from completion of the suture to emplacement of stage- 2 granite in the area.

\section{Rotations}

Declination values show large variation before and after the structure correction (Fig. 7, Table 2), while inclinations are somewhat uniform in geographic coordinates. As discussed earlier this high angle variation of declinations may be due to structural rotation about vertical axes with out disturbing the inclination values after the acquisition of magnetization. These volcanics are bounded by two thrusts (Fig. 2). Paleomagnetic method combined with the structure work has potential to distinguish between different causes of differential rotations related with thrust sheets (McCaig and McClelland, 1992). No systematic variation of declination is observed between different sites. This type of variable rotations with in thrust sheet may be because of the pinning and dragging at the margin of the thrust sheet (Simon, 1998). Non availability of structural data and complicated situation arising from remagnetization of these volcanics stop us from further interpretation. However discordant declination pattern is not rare in thrust-belt regions (Klootwijk et al., 1986; Pares et al., 1994; Van der Voo et al., 1997; Yoshida et al., 1998; Zaman and Torii, 1999). The latter stage deforma- tion in the rocks, north of the Dir thrust may produce local scale rotations related with thrust sheet deformations. Two major north-south trending faults nearby sampling area are providing the evidence of intensive deformation suffered by the studied area (Fig. 2). As inclinations are consistent in geographic coordinates and encountered ChRM is post folding, therefore the scattering of declinations is due to post folding rotational phenomena.

Some times internal deformation related to thrust sheets produce grain rotation. This phenomena generate scattering of primary directions and apparent syn-folding magnetization is observed (Stamatakos and Kodama, 1991) There is no structure evidence for plastic deformation in these rocks, but brittle deformation is observed as major mode of stress accommodation (Sullivan et al., 1993).

\section{Future Recommendations}

Further paleomagnetic data is needed in order to explore the nature of the ChRM acquired by magnetite and hematite and of complex differential rotations related with thrust sheet. Besides this detail structural work is required to explain the cause of complex rotations in these volcanics. The lack of knowledge of timing of metamorphic events, which are contributing to thermochemical magnetizations, seems to be one of the obstacles in interpreting the data unambiguously. The dating of different thermochemical events suffered by these volcanics will be of great use in order to assign the precise ages to secondary magnetizations.

\section{Conclusions}

In this study only part of Utror Volcanic Formation is covered, more data is highly needed to reach at better conclusion. Moreover due to complicated rotations and remagnetization processes in these volcanics it is difficult to interpret the data unambiguously. However on the basis of the present study following main points can be concluded.

1. On the basis of magnetic mineralogical studies the potential remanent carriers of the Utror Volcanic Formation are maghemite, magnetite, titanomagnetite, hematite and titanohematite. Magnetic carrier for characteristic remanent magnetization component is variable in samples of different sites. ChRM are post folding secondary magnetizations. ChRM carried by magnetite are having downward inclinations, while ChRM carried by hematite assemblages are having upward inclinations. This correlation may be because of formation of two mineral assemblages at different polarities during different remagnetization processes.

2. ChRM was acquired at low northern paleolatitudes ( $9 \sim$ $13^{\circ} \mathrm{N}$ ) during the interaction of the volcanics with collision related orogenic fluids 55-45 Ma ago. This is the age ranging from completion of the suture to the final emplacement of suduction related plutons in the area.

3. As declination data is highly dispersed, individual sites may have suffered complex differential rotations related with thrust sheet deformations after the acquisition of post folding secondary ChRM. 
Acknowledgments. We are grateful to Iftikhar Mustafa Khadim, Drs. Mohammad Ali, Tahseen and A. B. Kausar for their help in initial fieldwork. Part of the research was supported by Geoscience Laboratory Project, a technical cooperation project between GSP (Geological Survey of Pakistan) and JICA (Japan International Cooperation Agency). Dr. Pitambar Gautam and Pen Welang are acknowledged for reviews of early draft of the manuscript. Mrs. Atyia Tun-Noor Shema is acknowledged for drawing the figures. We are grateful to R. J. Enkin (Geological Survey of Canada) for paleomagnetic software. Critical reviews by Drs. Stuart Gilder and Jason R. Ali helped a lot in improving the present manuscript.

\section{References}

Ade-Hall, J. M., H. C. Palmer, and T. P. Hubbard, The magnetic and opaque Petrological response of basalts to regional hydrothermal alteration, Geophys. J. R. astr. Soc., 24, 137-174, 1971.

Ahmad, M. N. and M. Yoshida, Paleomagnetism of upper Cretaceous granite and Paleogene volcanics in Kalam area, Northern Pakistan, in Paleomagnetism of Collision Belts, edited by I. M. Khadim, H. Zaman, and M. Yoshida, 239 pp., Geoscience Laboratory, Geol. Surv. Pakistan, 1997.

Cas, R. A. F. and J. V. Wright, Volcanic Successions Modern and Ancient, 528 pp., Allen and Unwin Ltd., London, 1987.

Coward, M. P., R. W. H. Butler, M. A. Khan, and R. J. Knipe, The tectonic history of Kohistan and its implications for Himalayan structures, J. Geol. Soc. London, 144, 377-391, 1987.

Debon, F., P. Le Fort, S. M. F. Sheppard, and J. Sonet, The four plutonic belts of the Transhimalaya-Himalaya: a chemical, mineralogical, isotopic and chronological synthesis along a Tibet-Nepal section, J. Petrol., 27, 219-250, 1986.

Enkin, R. J. and G. S. Watson, Statistical analysis of paleomagnetic inclination data, Geophys. J. Int., 126, 495-504, 1996.

Fisher, R. A., Dispersion on a sphere, Proc. R. Soc. London, A, 217, 295 $305,1953$.

Gautam, P., Multi-Component Remanent Magnetization in Aulis Volcanics, the lesser Himalaya, Nepal, J. Geomag. Geoelectr., 41, 101-117, 1989.

Khan, M. A., R. J. Stern, R. F. Gribble, and B. F. Windley, Geochemical and isotopic constraints on subduction polarity, magma sources, and paleogeography of the Kohistan intra-oceanic arc, northern Pakistan Himalaya, J. Geol. Soc. London, 154, 935-946, 1997.

Kirschvink, K. L., The least square line and plane and the analysis of paleomagnetic data, Geophys. J. R. astr. Soc., 62, 699-718, 1980.

Klootwijk, C. T., M. L. Sharma, J. Gergan, B. Tirkey, S. K. Shah, and V. Agarwal, The Extend of Greater India, II. Paleomagnetic data from the Ladakh intrusives at Kargil, Northwestern Himalayas, Earth Planet. Sci. Lett., 44, 47-64, 1979.

Klootwijk, C. T., M. L. Sharma, J. Gergan, S. K. Shah, The Indus-Tsangpo suture zone in Ladakh, Northwest Himalaya: Further paleomagnetic data and implications, Tectonophys., 106, 215-238, 1984.

Klootwijk, C. T., P. J. Conaghan, and C. McA. Powell, The Himalayan Arc: Large scale continental subduction, oroclinal bending and back-arc spreading, Earth Planet. Sci. Lett., 75, 167-183, 1985.

Klootwijk, C. T., M. L. Sharma, J. Gergan, S. K. Shah, and B. K. Gupta, Rotational overthrusting of northwestern Himalaya: further paleomagnetic evidence from the Risai thrust sheet, Jammu foothills, India, Earth Planet. Sci. Lett., 80, 375-393, 1986.

Klootwijk, C. T., J. S. Gee, J. W. Peirce, and G. M. Smith, Constraints on the India-Asia convergence: paleomagnetic results from Ninetyeast Ridge, in Proc. ODP, Sci. Results, No. 121, edited by J. Weissel, J. Peirce, E. Taylor, and J. Alt, pp. 777-881, 1991.

Klootwijk, C. T., J. S. Gee, J. W. Peirce, G. M. Smith, and P. L. McFadden, An early India-Asia contact: Paleomagnetic constraints from Ninetyeast Ridge, ODP Leg 121, Geology, 20, 395-398, 1992.

Klootwijk, C. T., P. J. Conaghan, R. Nazirullah, and K. A. De Jong, Further paleomagnetic data from Chitral (Eastern Hindukush): evidence for an early India-Asia contact, Tectonophys., 237, 1-25, 1994.

Le Fort, P., Evolution of the Himalaya, in The Tectonic Evolution of Asia, edited by A. Yin and M. Harrison, 666 pp., Cambridge University Press, 1996.

McCaig, A. M. and McClelland, Paleomagnetic techniques applied to thrust belts, in Thrust Tectonic, edited by K. R. McClay, 447 pp., Chapman \& Hall, 1992.
McElhinny, M. W., Statistical Significance of the fold test in paleomagnetism, Geophys. J. R. astr. Soc., 8, 338-340, 1964.

McFadden, P. L., The fold Test as an analytical tool, Geophys. J. Int., 135, 329-338, 1998.

McFadden, P. L. and A. B. Reid, Analysis of paleomagnetic inclination data, Geophys. J. R. astr. Soc., 69, 307-319, 1982.

O‘ Reilly, W., Rock and Mineral Magnetism, 220 pp., Blackie, Glasgow, 1984

Pares, M. J., R. Van der Voo, and J. Stamatakos, Remagnetizations and postfolding oroclinal rotations in the Cantabrian/Asturian arc, north Spain Tectonics, 13, 1461-1471, 1994.

Petterson, M. G. and B. F. Windley, Rb-Sr dating of the Kohistan arcbatholith in the Trans Himalaya of north Pakistan, and tectonic implications, Earth Planet. Sci. Lett., 74, 45-57, 1985.

Pullaiah, G., E. Iriving, K. L. Buchan, and D. C. Dunlop, Magnetization changes caused by burial and uplift, Earth Planet. Sci. Lett., 28, 133143

Searle, M. P., Geology and Tectonics of the Karakoram Mountains, 358 pp., John Wiley \& Sons, 1991.

Searle, M. P., Cooling history, erosion, exhumation, and kinematics of Himalaya-Karakoram-Tibet orogenic belt, in The Tectonic Evolution of Asia, edited by A. Yin and M. Harrison, 666 pp., Cambridge University Press, 1996.

Shah, M. T. and J. W. Shervais, The Dir-Utror metavolcanic sequence, Kohistan arc terrane, northern Pakistan, J. Asian, Earth Sciences, 17, 459475, 1999.

Simon, A., Geometry and kinematics of vertical-axis rotations in fold and thrust belts, Tectonophys., 299, 15-30, 1998.

Stamatakos, J. and K. P. Kodama, Flexture flow folding and the Paleomagnetic fold test: An example of strain reorientation of remanence in the Mauch Chunk Formation, Tectonics, 10, 807-819, 1991.

Sullivan, M. A., B. F. Windley, A. D. Saunders, J. R. Haynes, and D. C. Rex, A paleogeographic reconstruction of the Dir Group: evidence for magmatic arc migration within Kohistan, N. Pakistan, in Himalayan Tectonics, edited by P. J. Treloar and M. P. Searle, Geol. Soc. Specl. Publi. 74, 139-160, 1993.

Tahirkheli, R. A. K., M. Mattauer, F. Proust, and P. Tapponnier, The IndiaEurasia suture zone in northern Pakistan: Some new data for interpretation at plate scale, in Geodynamics of Pakistan, edited by A. Farah and K. A. DeJong, pp. 125-130, Geol. Surv. Pakistan, Quetta, 1979.

Treloar, P. J., D. C. Rex, P. G. Guise., M. P. Coward, M. P. Searle, B. F. Windeley, M. G. Petterson, M. Q. Jan, and I. W. Luff, K-Ar and Ar-Ar geochronology of Himalayan collision in NW Pakistan: constraints on the timming of suturing, deformation, metamorphism and uplift, Tectonics, 8, 881-909, 1989

Treloar, P. J., M. G. Petterson, M. Q. Jan, and M. A. Sullivan, A re-evaluation of the stratigraphy and evolution of Kohistan arc sequence, Pakistan Himalaya: implications for magmatic and tectonic arc building processes, J. Geol. Soc. London, 153, 681-693, 1996.

Van der Voo, R., J. A. Stamatakos, J. M. Pares, Kinematic constraints on thrust belt curvature from syndeformational magnetizations in Lagos del Valle Syncline in Cantabrian Arc, Spain, J. Geophys. Res., 102, 10,10510,119, 1997

Watson, G. S. and R. J. Enkin, The fold test in paleomagnetism as a parameter estimation problem, Geophys. Res. Lett., 20, 2135-3137, 1993.

Yoshida, M., I. H. Khan, and M. N. Ahmad, Remanent magnetization of oolitic ironstone beds, Hazara area, lesser Himalayan thrust zone, Northern Pakistan: Its acquisition, timing, and paleoenvironmental implications, Earth Planets Space, 50, 733-744, 1998.

Zaman, H. and M. Torri, Paleomagnetic study of Cretaceous red beds from eastern Hindukush ranges, northern Pakistan: paleoreconstruction of the Kohistan-Karakoram composite unit before the India-Asia collision, Geophys. J. Int., 136, 719-738, 1999.

Zeitler, P. K., Cooling History of the NW Himalaya, Tectonics, 4, 127-151, 1985.

Zijderveld, J. D. A., A. C. demagnetization of rocks: Analysis of results, in Methods in Paleomagnetism, edited by D. W. Collinson, K. M. Creer, and S. K. Runcorn, 609 pp., Elsevier, Amsterdam, 1967.

M. N. Ahmad (e-mail: naseer@ep.sci.hokudai.ac.jp), M. Yoshida, and Y. Fujiwara 